\section{PENYELESAIAN KREDIT MACET MELALUI PENGADILAN $^{1}$ \\ Oleh: Tiska L. Pomantow ${ }^{2}$}

\section{ABSTRAK}

Tujuan dilakukannya penelitian ini adalah untuk mengetahui bagaimanakah bentuk kegiatan perbankan dan kelayakan operasional bank dan bagaimanakah penyelesaian kredit macet melalui pengadilan. Melalui penelitian hukum normatif disimpulkam bahwa: 1 . Tugas dan tanggung jawab dari sebuah bank mencakup kegiatan menghimpun dana dari masyarakat, menyalurkan kembali dana yang dihimpun tersebut kepada masyarakat/dunia usaha yang membutuhkan, serta menyediakan layanan jasa-jasa tertentu di bidang keuangan dan perbankan. Reputasi perbankan nasional dipengaruhi oleh kualitas dan integritas para bankirnya, yang harus mampu ditunjukkan oleh para bankir nasional untuk menjawab tudingan sementara kalangan mengenai korelasinya dengan banyaknya kredit macet yang terdapat pada bank-bank umum dewasa ini, khususnya di bank BUMN. 2. Kredit macet yang terjadi di bank BUMN diketegorikan sebagai mengakibatkan kerugian negara, karena modal bank BUMN berasal dari kekayaan negara yang dipisahkan. Ditinjau dari sudut hukum perdata, makna kekayaan negara yang dipisahkan berarti bahwa negara seharusnya tidak dibenarkan mencampuri pengelolaan korporasi yang dilakukan pengurus bank BUMN tersebut. Apabila terjadi kelalaian yang dilakukan oleh direksi dan mengakibatkan kerugian bagi bank BUMN, pertanggungjawaban dapat dimintakan secara perdata melalui gugatan ke pengadilan bukan pidana, kecuali RUPS menentukan lain.

\footnotetext{
${ }^{1}$ Artikel skripsi. Dosen pembimbing skripsi: Dr. Merry E. Kalalo,SH,MH, Djefry W. Lumintang, $\mathrm{SH}, \mathrm{MH}$, Alsam Polontalo,SH,MH.

${ }^{2}$ NIM: 090711676.
}

Kata kunci: kredit macet

\section{PENDAHULUAN}

\section{A. Latar Belakang Masalah}

Apabila terjadi tunggakan-tunggakan dan mengarah kepada timbulnya kredit macet, maka pihak Bank pada umumnya mencari berbagai jalan keluar penyelamatan sesuai kondisinya, akan tetapi seringkali posisi debitur sudah tidak tertolong lagi atau memang debitur tidak punya itikad baik untuk melunasi. Masalah yang muncul kemudian adalah adanya kemacetan kredit yang jika tidak terselesaikan secara damai maka langkah Bank selanjutnya lebih diwarnai dengan penyelesaian melalui jalur hukum di mana Bank Swasta melalui Pengadilan Negeri dan untuk Bank Pemerintah melalui Panitian Urusan Piutang Negara (PUPN)/Direktorat Jenderal Piutang dan Lelang Negara (DJPLN). Namun terdapat juga Bank Pemerintah (BUMN) yang penyelesaiannya melalui pengadilan

\section{B. Perumusan Masalah}

1. Bagaimanakah bentuk kegiatan perbankan dan kelayakan operasional bank?

2. Bagaimanakah penyelesaian kredit macet melalui pengadilan?

\section{E. Metode Penelitian}

Penelitian ini merupakan penelitian hukum normatif yang merupakan salah satu jenis penelitian yang dikenal umum dalam kajian ilmu hukum. Data sekunder, berupa penelitian kepustakaan dilakukan terhadap pelbagi macam sumber-sumber bahan hukum yang dapat diklarifikasikan menjadi 3 (tiga) jenis, yaitu: ${ }^{3}$ bahan hukum primer, bahan hukum sekunder, dan bahan hukum tersier.

\footnotetext{
${ }^{3}$ Ibid, hlm. 13, lihat pula: Peter Mahmud Marzuki, Penelitian Hukum, Penerbit Kencana Prenada Media Group, Jakarta, 2005, hlm. 141.
} 


\section{PEMBAHASAN}

\section{A. KEGIATAN PERBANKAN DAN OPERASIONALISASI BANK}

Dalam literatur perbankan ditemukan berbagai jenis dan macam bank yang digolongkan baik menurut fungsinya, fokus segmen pasarnya, kepemilikannya, maupun kelompok usahanya. Di antara berbagai jenis ragam bank dimaksud, yang paling banyak dikenal di masyarakat luas pada umumnya yaitu Bank Umum, Bank Perkreditan Rakyat (BPR), Bank Investasi (Investment Bank), Bank Devisa, Bank Korporasi (Corporate Bank), Bank Ritel (Retailed Bank), Bank Syariah (Bank Bagi Hasil), dan Bank Pembangunan Daerah (Regional Development Bank). ${ }^{4}$ Di dalam UU Perbankan sendiri hanya dikenal 2 (dua) jenis bank yakni Bank Umum dan Bank Perkreditan Rakyat (BPR), sedang mengenai jenis-jenis bank lainnya sebagaimana yang disebutkan di atas tidak dikenal lagi dalam UU Perbankan tersebut. Hal ini disebabkan sejak tahun 1992 ketentuan perundang-undangan di bidang perbankan telah melakukan penyempurnaan terhadap industri perbankan di Indonesia melalui penyederhanaan jenis bank, peningkatan perlindungan dana masyarakat yang disimpan ke perbankan melalui penerapan prinsip kehati-hatian (prudent banking practice), pemenuhan ketentuan persyaratan kesehatan bank, dan peningkatan profesionalisme dari para bankir. $^{5}$

Menurut ketentuan UU Perbankan, bentuk hukum sebuah bank di Indonesia dapat berupa Perseroan Terbatas (PT), koperasi, atau Perusahaan Daerah (PD). ${ }^{6}$

\footnotetext{
${ }^{4}$ Munir Fuady, Hukum Perbankan Modern, Buku Kesatu, (Bandung: Citra Aditya Bakti, 2003), hlm. 15.

${ }^{5}$ Bagian Penjelasan UU Nomor 7 Tahun 1992 tentang Perbankan.

${ }^{6}$ Pasal 21 UU Nomor 10 Tahun 1998 tentang Perubahan Atas Undang-Undang Nomor 7 Tahun 1992 tentang Perbankan.
}

Tentang Perseroan Terbatas, Pasal 1 UU No. 1 Tahun 1995 tentang Perusahaan Terbatas (sebagaimana telah dirobah dengan Undang-Undang No. 40 Tahun 2007) menyebutkan bahwa: "Perseroan Terbatas adalah badan hukum yang merupakan persekutuan modal, didirikan berdasarkan perjanjian, melakukan kegiatan usaha dengan modal dasar yang seluruhnya terbagi dalam saham dan memenuhi persyaratan yang ditetapkan dalam Undang-Undang ini serta peraturan pelaksanaannya".

Dari ketiga bentuk hukum dari sebuah bank sebagaimana yang dikemukakan di atas, bentuk hukum PT lebih banyak ditemukan dalam praktek karena lebih mampu untuk menampung kegiatan perbankan yang cakupannya begitu luas. Badan hukum PD hanya dimiliki oleh pemerintah daerah yang mendirikan bank guna menunjang dan menampung kegiatan pembangunan di daerahnya. Bank dengan bentuk hukum Koperasi jarang ditemukan dalam praktek, antara lain karena perbankan membutuhkan penyediaan modal dalam jumlah besar yang tidak mampu untuk disediakan oleh badan hukum berbentuk Koperasi yang mengumpulkan dana berupa iuran dari para anggotanya, dan juga dunia perbankan dewasa ini yang harus fleksibel untuk menghadapi tantangan yang sangat dinamis.

Tugas dan tanggung jawab dari sebuah bank secara umum mencakup aktivitas: ${ }^{7}$

1) Menerima cash dan membayar dokumentasi yang harus dibayar oleh nasabah, seperti terhadap cek, pengiriman uang, bills of exchange dan lain-lain instrumen perbankan.

2) Membayar kembali uang nasabah yang ditempatkan di bank tersebut apabila dimintakan oleh pihak nasabah.

3) Meminjamkan uang kepada nasabah.

\footnotetext{
${ }^{7}$ Munir Fuady, Op.Cit, hlm. 16.
} 
4) Menjaga kerahasiaan mengenai account dari nasabah dalam hubungannya dengan kerahasiaan bank, kecuali apabila ditentukan lain oleh peraturan perundang-undangan.

5) Jika pihak nasabah mempunyai 2 (dua) rekening atau lebih, terdapat kewajiban moral bagi bank untuk membuat rekening tersebut terpisah satu sama lainnya.

6) Jika rekening ditutup, bank harus mempunyai alasan yang reasonable untuk menutup rekening tersebut.

Secara singkat tugas dan tanggung jawab dari sebuah bank dapat digolongkan ke dalam 3 (tiga) kegiatan pokok yakni kegiatan menghimpun dana dari masyarakat, menyalurkan kembali dana yang dihimpun tersebut kepada masyarakat/dunia usaha yang membutuhkan, serta menyediakan layanan jasa-jasa tertentu di bidang keuangan dan perbankan. ${ }^{8}$ Setiap kegiatan menghimpun dana dari masyarakat, baik dalam bentuk simpanan maupun dalam bentuk lainnya, diwajibkan untuk terlebih dahulu memperoleh izin usaha perbankan dari Bank Indonesia, dan barang siapa yang melakukan kegiatan menghimpun dana tersebut tanpa terlebih dahulu mendapatkan izin akan dikenakan hukuman, baik berupa sanksi administratif maupun hukuman pidana penjara. ${ }^{9}$

UU Perbankan memperkenankan bank umum untuk melakukan kegiatan-kegiatan sebagai berikut: ${ }^{10}$

1. Menghimpun dana dari masyarakat dalam bentuk simpanan berupa giro, deposito berjangka, sertifikat deposito, tabungan, dan/atau bentuk lainnya yang dipersamakan dengan itu.

2. Memberikan kredit.

\footnotetext{
8 Ibid, hlm 8.

${ }^{9}$ Pasal 16 dan Pasal 46 UU Nomor 10 Tahun 1998 juncto No. 7 Tahun 1992 tentang Perbankan.

${ }^{10}$ Pasal 6 UU Nomor 10 Tahun 1998 juncto No. 7 Tahun 1992 tentang Perbankan.
}

3. Menerbitkan surat pengakuan utang.

4. Membeli, menjual atau menjamin atas risiko sendiri maupun untuk kepentingan dan atas perintah nasabahnya:

a. Surat-surat wesel termasuk wesel yang diakseptasi oleh bank yang masa berlakunya tidak lebih lama daripada kebiasaan dalam perdagangan surat-surat dimaksud.

b. Surat pengakuan utang dan kertas dagang lainnya yang masa berlakunya tidak lebih lama dari kebiasaan perdagangan suratsurat dimaksud.

c. Kertas Perbendaharaan Negara dan surat jaminan pemerintah.

d. Sertifikat Bank Indonesia ( SBI ).

e. Obligasi.

f. Surat dagang berjangka waktu sampai dengan 1 (satu) tahun.

g. Instrumen surat berharga lain yang berjangka waktu sampai dengan 1 (satu) tahun.

5. Memindahkan uang baik untuk kepentingan sendiri maupun untuk kepentingan nasabah.

6. Menempatkan dana pada, meminjam dana dari, atau meminjamkan dana kepada bank lain, baik dengan menggunakan surat, sarana telekomunikasi maupun dengan wesel unjuk, cek atau sarana lainnya.

7. Menerima pembayaran dari tagihan atas surat berharga dan melakukan perhitungan dengan atau antar pihak ketiga.

8. Menyediakan tempat untuk menyimpan barang dan atau surat berharga.

9. Melakukan kegiatan penitipan untuk kepentingan pihak lain berdasarkan suaiu kontrak.

10. Melakukan penempatan dana dari nasabah kepada nasabah lainnya dalam 
bentuk surat berharga yang tidak tercatat di bursa efek.

11. Membeli melalui pelelangan agunan baik semua maupun sebagian dalam hal debitur tidak dapat memenuhi kewajibannya kepada bank, dengan ketentuan agunan yang dibeli tersebut wajib dicairkan secepatnya.

12. Melakukan kegiatan anjak piutang, usaha kartu kredit dan kegiatan wah amanat.

13. Menyediakan pembiayaan dan atau melakukan kegiatan lain berdasarkan prinsip syariah, sesuai dengan ketentuan yang ditetapkan oleh Bank Indonesia.

14. Melakukan kegiatan lain yang lazim dilakukan oleh bank sepanjang tidak bertentangan dengan peraturan perundang-undangan yang berlaku.

Selain dari hal-hal yang telah disebutkan di atas, bank umum dapat pula melibatkan diri dalam:

1. Melakukan kegiatan dalam valuta asing dengan memenuhi ketentuan yang ditetapkan oleh Bank Indonesia.

2. Melakukan kegiatan penyertaan modal pada bank atau perusahaan lain di bidang keuangan, seperti sewa guna usaha, modal ventura, perusahaan efek, asuransi, serta lembaga kiiring penyelesaian dan penyimpanan, dengan memenuhi ketentuan yang ditetapkan oleh Bank Indonesia.

3. Melakukan kegiatan penyertaan modal sementara untuk mengatasi akibat kegagalan kredit atau kegagalan pembiayaan berdasarkan prinsip syariah, dengan syarat harus menarik kembali penyertaannya, dengan memenuhi ketentuan yang ditetapkan oleh Bank Indonesia, dan

4. Bertindak sebagai pendiri dana pensiun dan pengurus dana pensiun sesuai dengan ketentuan dalam peraturan pertmdang-undangan dana pensiun yang berlaku.
Dari gambaran kegiatan bank umum tersebut dapat dilihat bahwa fungsi perbankan sedemikian luasnya dan bersentuhan dengan sendi-sendi kehidupan ekonomi dan kegiatan masyarakat. Agar perbankan tidak melakukan kegiatan penyertaan modal secara umum yang tidak merupakan kegiatan intinya, UU Perbankan melarang bank untuk melakukan kegiatan penyertaan modal pada perusahaan di luar dari tujuan untuk penyelamatan kredit (credit recovery). Selain dari itu, perbankan juga dilarang untuk melakukan kegiatan perasuransian karena kegiatan dimaksud mengandung risiko yang besar, demi menghindarkan diri dari risiko yang tidak melekat pada kegiatan perbankan. ${ }^{11}$ Bank juga dikenakan larangan untuk melakukan aktivitas jual beli saham ataupun memiliki saham yang terdaftar di pasar modal. ${ }^{12}$ Larangan ini erat kaitannya dengan harga saham di bursa yang berfluktuasi setiap harinya. Apabila bank mempunyai aktiva dalam bentuk portofolio saham yang diperdagangkan secara aktif di bursa, permodalan bank dapat tergerus sewaktuwaktu sebagai akibat dari mekanisme transaksi yang terjadi setiap harinya di bursa tersebut, yang pada akhirnya akan mengakibatkan Rasio Permodalan Bank (Capital Adequacy Ratio) menjadi tidak mencukupi.

\section{Kelayakan Operasional Bank}

Di kebanyakan negara, kegiatan perbankan termasuk ke dalam industri yang diatur secara ketat oleh pemerintah dan bahkan sementara kalangan di Indonesia menganggap pengaturan perbankan sebagai hal yang berlebihan (excessively regulated). Hal ini berkaitan erat dengan fungsi perbankan yang sedemikian

\footnotetext{
${ }^{11}$ Pasal 10 ayat b. UU Nomor 10 Tahun 1998 juncto Nomor 7 Tahun 1992 tentang Perbankan.

${ }^{12}$ Pasal 4 ayat 2.a. Keputusan Direksi Bank Indonesia No. 24/33/KEP/DIR tanggal 12 Agustus 1991 tentang Pemilikan Saham dan Penyertaan.
} 
strategis, goncangan yang dialami perbankan dapat meruntuhkan kredibilitas perekonomian suatu negara. Selain dapat mempengaruhi jumlah uang yang beredar di masyarakat, perbankan juga berperan untuk memberikan stimulus dalam peningkatan perekonomian nasional, serta menjembatani kebutuhan-kebutuhan finansial masyarakat, yang keseluruhan dari aktivitas yang disebutkan di atas mengandung risiko yang besar (high risk). Risiko yang menimpa perbankan dapat terjadi sewaktu-waktu karena sebagian besar dari aktiva dan kewajiban yang tercantum dalam pembukuan bank terdiri dari unit-unit moneter (monetary units) yang sifatnya sangat gampang pecah (fragile). Volatilitas yang terjadi pada nilai tukar, turbulensi moneter dan guncangan di pasar modal, maupun rumor negatif yang menimpa dunia perbankan dapat mengakibatkan unit-unit moneter tersebut mengalir keluar secara seketika dari dalam bank, yang pada akhirnya akan membuat bank mengalami kesulitan likuiditas, dan apabila tidak cepat diatasi akan meruntuhkan bank dimaksud.

Ketentuan perundang-undangan yang menyangkut perbankan menyebutkan bahwa untuk dapat melaksanakan kegiatan usahanya, sebuah bank harus terlebih dahulu memperoleh izin usaha dari instansi yang berwenang. Pasal 16 UU Perbankan menyebutkan bahwa:

(1) Setiap pihak yang melakukan kegiatan menghimpun dana dari masyarakat dalam bentuk simpanan wajib terlebih dahulu memperoleh izin usaha sebagai Bank Umum atau Bank Perkreditan Rakyat dari Pimpinan Bank Indonesia, kecuali apabila kegiatan menghimpun dana dari masyarakat dimaksud diatur dengan undangundang tersendiri.

(2) Untuk memperoleh izin usaha Bank Umum dan Bank Perkreditan
Rakyat sebagaimana dimaksud dalam ayat (1), wajib dipenuhi persyaratan sekurang-kurangnya tentang:

a) susunan organisasi dan kepengurusan;

b) permodalan;

c) kepemilikan

d) keahlian di bidang perbankan;

e) dan kelayakan rencana kerja.

\section{B. PERTANGGUNGJAWABAN BANKIR ATAS KREDIT MACET SERTA PENYELESAIANNYA MELALUI PENGADILAN}

Dunia perbankan Indonesia kembali dilanda kredit bermasalah. Berdasarkan audit BPK, setidaknya 24 kredit yang disalurkan Bank Mandiri senilai Rp 2 triliun lebih macet. ${ }^{13}$ Pengucuran kredit tersebut diduga diwarnai kolusi antara pejabat Bank Mandiri dan debitur. Hal ini terindikasi dari adanya permohonan kredit yang semula dinyatakan tidak layak, namun kredit tetap dikucurkan. Oleh karena itu, pemeriksaan terhadap direksi Bank Mandiri dimaksudkan untuk menguak keterlibatan mereka dalam pengucuran kredit tersebut.

Sebenarnya skandal Bank Mandiri hanya sebagian kecil dari segudang kasus kredit macet yang terjadi di lembaga perbankan Indonesia. Masih banyak konglomerat menikmati fasilitas kredit, baik yang dikucurkan karena KKN atau kroniisme yang jumlahnya boleh jadi melebihi kredit Bank Mandiri. Kita patut prihatin melihat tingginya angka kredit macet di Indonesia. Yang lebih memprihatinkan lagi, dari sejumlah kasus kredit macet tersebut, sebagian besar yakni sekitar 60-70\%, diderita bank pemerintah.

13

http://ferina061192.blogspot.com/2012/04/kasusaspek-hukum-dalam-ekonomi-tugas.html 
Berbagai upaya telah ditempuh pemerintah untuk menekan kuantitas kredit macet di lembaga perbankan. Pemerintah pernah membentuk Tim Supervisi Kredit Bermasalah Bank Pemerintah guna memantau penyelesaian kredit macet. Kemudian diluncurkan program sistem informasi kredit (SIK) antarbank untuk mengetahui nasabah (debitur) yang mempunyai catatan buruk karena pernah memacetkan kredit.

Manakala langkah preventif mengalami kebuntuan dalam menyelesaikan kredit macet, ditempuhlah upaya represif yaitu diselesaikan melalui pengadilan. Upaya tersebut dilakukan mengingat pengadilan merupakan benteng terakhir bagi setiap orang untuk menyelesaikan segala persoalan, termasuk kredit macet. Sebelum ditempuh jalur pengadilan, biasanya bank mencoba mengupayakan penyelesaian secara musyawarah dengan melakukan rescheduling, reconditioning, dan restructuring terhadap perusahaan (debitur) penunggak kredit. Apabila upaya tersebut tidak juga berhasil, tidak tertutup kemungkinan diselesaikan melalui jalur hukum dengan melibatkan institusi pengadilan.

Sebelum ditempuh penyelesaian melalui jalur hukum, perlu kiranya diketahui apakah persoalan kredit macet termasuk dalam lingkup hukum perdata atau pidana. Pada asasnya kredit macet merupakan persoalan hukum perdata, yaitu hubungan personal antara perseorangan atau badan hukum yang satu dengan lainnya di bidang harta kekayaan.

Dalam terminologi hukum perdata hubungan antara debitur (peminjam kredit) dan kreditor (bank atau LKBB selaku pemberi kredit) merupakan hubungan utang piutang yang lahir dari apa yang disebut perjanjian, yakni kedua belah pihak berjanji untuk melaksanakan hak dan kewajiban masing-masing.
Pihak debitur dengan memperoleh kredit dari bank berjanji kepada kreditor (bank) untuk mengembalikan kredit beserta biaya dan bunga sesuai waktu yang telah disepakati bersama. Untuk menjamin dilaksanakannya janji tersebut debitur memberikan pengikat yang lazim disebut jaminan atau agunan, baik kebendaan maupun perorangan.

Dengan adanya jaminan tersebut, manakala debitur ingkar janji, yaitu tidak memenuhi kewajiban sesuai perjanjian, kreditor dapat menuntut pemenuhan utang dari barang jaminan. Kreditor dapat meminta dilakukan penyitaan dan penjualan lelang atas agunan dan aset lain milik debitur jika agunan tidak mencukupi untuk membayar utang.

Kasus kredit macet, yang pada dasarnya merupakan persoalan hukum perdata, tidak tertutup kemungkinan bersinggungan dengan hukum pidana. Tindakan cepat Kejaksaan Agung yang menjadikan empat debitur Bank Mandiri sebagai tersangka didasarkan pada adanya indikasi kuat telah terjadi tindak pidana dalam pengucuran kredit tersebut.

Aspek kriminal dari kasus kredit macet umumnya terjadi pada saat proses permohonan kredit dan pada saat pengucuran kredit. Ketika permohonan kredit diajukan, tidak jarang terjadi kenakalan debitur, baik sendiri atau atas kerja sama dengan pejabat bank, seperti melakukan kolusi dan konspirasi dalam penyaluran kredit. KKN antara debitur dan pejabat bank agaknya sudah mentradisi dalam penyaluran kredit, terutama di bank pemerintah. Akibat diwarnai KKN maka banyak terjadi pengucuran kredit meski tanpa didahului akad kredit atau tanpa agunan yang safe. Dalam skandal Bapindo yang melibatkan Edy Tanzil beberapa tahun lalu terjadi penyuapan uang ratusan juta kepada direksi Bapindo dan pejabat terkait guna mengucurkan kredit Rp1,3 triliun. 
Menurut Pasal 49 ayat 2 UU Perbankan (UU No 7/1992 jo UU No 10/1998) pejabat bank (komisaris, direksi, atau pegawai), baik pada bank swasta atau bank pemerintah, yang melakukan kolusi dengan debitur untuk mempermudah pemberian kredit, diancam penjara minimal 3 tahun maksimal 8 tahun dan denda minimal Rp5 miliar maksimal Rp100 miliar.

Apabila kolusi dilakukan oleh pejabat bank pemerintah yang mengakibatkan kerugian negara, dapat dijerat UU Korupsi (UU No 3/1971 jo UU No 31/1999) dengan ancaman hukuman seumur hidup, atau penjara paling lama 20 tahun dan denda paling tinggi Rp30 juta. Bahkan, jika korupsi tersebut merugikan negara dalam jumlah amat besar dan berpengaruh luas terhadap kehidupan masyarakat, diancam pidana mati.

Jadi, sudah jelas bahwa perangkat hukum pidana dan perdata telah memberikan pedoman dalam penyelesaian kasus kredit macet. Persoalannya sekarang adalah apakah peranti hukum yang tersedia tersebut telah didayagunakan secara optimal dan konsisten oleh pemerintah dalam menyelesaikan kasus kredit macet di Indonesia.

Penyelesaian secara internal, seperti rescheduling, reconditioning, dan restructuring tidak boleh mengabaikan aspek hukum perdata jika memang perlu dilakukan. Apabila kasus kredit macet semata-mata karena masalah perdata murni, penyelesaian melalui jalur hukum perdata hendaknya ditempuh dengan baik. Kesemuanya itu dimaksudkan agar skandal kredit macet dapat diminimalisasi dari panggung perbankan kita. Namun, upaya penyelesaian melalui jalur hukum perdata tidak boleh menutup jalur hukum pidana jika memang terdapat indikasi terjadi tindak kriminal. Apabila dalam suatu kasus kredit macet terdapat bukti-bukti awal terjadinya pelanggaran hukum pidana, perbuatan tersebut harus ditindak secara tegas dan transparan.

Inkonsistensi penegakan hukum di samping mengakibatkan berlarut-larutnya penyelesaian kasus kredit macet, juga dapat menjadikan perangkat hukum kita mandul sehingga tidak mempunyai daya upaya untuk memaksa debitur nakal memenuhi kewajibannya. Ujung-ujungnya, yang dirugikan adalah lembaga perbankan dan negara secara keseluruhan.

Pada akhir-akhir ini, perkembangan hukum di bidang perbankan khususnya bagi bank BUMN yang menyalurkan kredit selalu dikaitkan dengan tindak pidana korupsi. Bank BUMN yang memiliki status Badan Usaha Milik Negara merupakan badan usaha yang seluruh atau sebagian besar modalnya dimiliki oleh negara melalui penyertaan secara langsung yang berasal dari kekayaan negara yang dipisahkan. ${ }^{14}$

Untuk memperoleh gambaran tentang proporsi Bank BUMN dalam kaitannya dengan keuangan negara, dibawah ini dikutip beberapa pasal dari UU Nomor 19 Tahun 2003 Tentang BUMN sebagai berikut:

Pasal 1 menyebutkan sebagai berikut:

Ayat (1) : BUMN adalah badan usaha yang seluruh atau sebagian besar modalnya dimiliki oleh negara melalui penyertaan secara langsung yang berasal dari kekayaan negara yang dipisahkan.

Ayat (2) : Perusahaan Perseroan, yang selanjutnya disebut sebagai Persero, adalah BUMN yang berbentuk perseroan terbatas yang modalnya terbagi dalam saham-saham yang seluruh atau paling

\footnotetext{
${ }^{14}$ Pasal 1 jo Pasal 4 UU Nomor 19 Tahun 2003 Tentang Badan Usaha Milik Negara.
} 
sedikit $51 \% \quad$ sahamnya dimiliki oleh negara Republik Indonesia yang tujuan utamanya mengejar keuntungan.

Ayat (10) : Kekayaan Negara yang dipisahkan adalah kekayaan negara yang berasal dari Anggaran Pendapatan dan Belanja Negara (APBN) untuk dijadikan penyertaan modal negara pada Persero dan/atau Perum serta perseroan terbatas lainnya.

Pasal 2 ayat (1) menyebutkan bahwa Maksud dan Tujuan Pendirian sebuah BUMN adalah untuk:

a) memberikan sumbangan bagi perkembangan perekonomian nasional pada umumnya dan penerimaan negara pada khususnya.

b) mengejar keuntungan.

c) menyelenggarakan kemanfaatan umum berupa penyediaan barang dan/atau jasa yang bermutu tinggi dan memadai bagi pemenuhan hajat hidup orang banyak.

d) menjadi perintis kegiatan-kegiatan usaha yang belum dapat dilaksanakan oleh sektor swasta dan koperasi.

e) turut aktif memberikan bimbingan dan bantuan kepada pengusaha golongan ekonomi lemah, koperasi, dan masyarakat.

Pasal 3 : Terhadap BUMN berlaku Undang-undang ini dan ketentuan peraturan perundang-undangan lainnya.

Pasal 4 : Modal BUMN merupakan dan berasal dari kekayaan negara yang dipisahkan.

Pasal 5 ayat (3) :
Dalam
melaksanakan
tugasnya

hams mematuhi anggaran dasar BUMN dan peraturan perundang-undangan serta wajib melaksanakan prinsipprinsip profesionalisme, efisiensi, transparansi, kemandirian, akuntabilitas, pertanggungjawaban, serta kewajaran.

Pasal 7 : Para anggota Direksi, Komisaris dan Dewan Pengawas dilarang mengambil keuntungan pribadi baik secara langsung maupun tidak langsung dari kegiatan BUMN selain penghasilan yang sah.

Pasal 11 : Terhadap Persero berlaku segala ketentuan dan prinsipprinsip yang berlaku bagi Perseroan Terbatas sebagaimana diatur dalam UU Nomor 1 Tahun 1995 (catatan: UU Nomor 1 Tahun 1995 telah diubah dengan UU Nomor 40 Tahun 2007).

Pasal 16 : (1) Anggota Direksi diangkat berdasarkan pertimbangan keahlian, integritas, kepemimpinan, pengalaman, jujur, perilaku yang baik, serta dedikasi yang tinggi untuk memajukan dan mengembangkan Persero.

(2) Pengangkatan anggota Direksi dilakukan melalui mekanisme uji kelayakan dan kepatutan.

Pasal 17 : Anggota Direksi sewaktuwaktu dapat diberhentikan berdasarkan keputusan RUPS dengan menyebutkan alasannya.

Pengertian keuangan negara dapat dilihat pada Pasal 1 angka 1 UU Nomor 17 Tahun 2003 Tentang Keuangan Negara, yang meliputi kekayaan negara yang 
dipisahkan maupun yang tidak dipisahkan. Kekayaan negara yang dipisahkan terdiri dari kekayaan negara yang berasal dari Anggaran Pendapatan dan Belanja Negara (APBN) untuk dijadikan penyertaan modal negara pada Persero dan/atau Perum serta perseroan terbatas lainnya, sebagaimana yang disebutkan pada UU Nomor 19 Tahun 2003 tentang BUMN.

Permasalahan yang kemudian timbul dan menyisakan perbedaan pendapat dan keraguan bagi banyak pihak. sampai saat ini adalah kalangan BUMN berpendapat bahwa pada saat kekayaan negara telah dipisahkan dari APBN, kekayaan tersebut bukan lagi masuk dalam wilayah hukum publik tetapi sudah menjadi wilayah hukum privat, sehingga kekayaan tersebut bukan lagi menjadi kekayaan negara melainkan telah menjadi kekayaan perseroan. Di pihak lain, kalangan penegak hukum masih melihat bahwa kekayaan negara yang dipisahkan ke dalam suatu perseroan tetap merupakan kekayaan negara, yang didasarkan kepada UU Tindak Pidana Korupsi yang menyatakan bahwa keuangan negara termasuk juga uang yang dipisahkan di BUMN.

Keruwetan dalam pengaturan keuangan negara berawal dari Pasal 23 UUD 1945 pasca perubahan, karena semua keuangan dalam Anggaran Pendapatan dan Belanja Daerah (APBD) dan BUMN Persero serta BUMD disebut sebagai kruangan negara. Padahal apabila ditinjau dari sudut sistem maupun ketentuan peraturan perundangundangan, pertanggungjawaban pengelolaan keuangan pada Pemda, BUMN, dan BUMD berbeda dengan yang ada pada APBN sebagai keuangan negara. Jika dilihat dari segi yuridis maupun dari segi fungsinya, terdapat perbedaan yang prinsipil antara keuangan negara, keuangan daerah, tnaupun keuangan BUMN Persero maupun BUMD. ${ }^{15}$ Melihat kepada urutan kejadian timbulnya beda penafsiran atas keuangan negara vs kekayaan negara yang disebutkan di atas, dapat dikatakan bahwa permasalahan ini timbul ke permukaan setelah adanya UU Keuangan Negara dan UUD 1945 pasca amandemen. Dengan UU Keuangan Negara, keberadaan BUMN Persero menjadi tidak tegas posisinya karena BUMN Persero masuk dalam tataran hukum publik. Namun, berdasarkan Pasal 11 UU BUMN disebutkan bahwa pengelolaan BUMN Persero harus dilakukan menurut kctentuan UU PT (saat ini UU Nomor 40 Tahun 2007). Kemudian, permasalahannya makin mencuat dengan keluarnya Fatwa Mahkamah Agung No. 10/MA/Yud/20/VIII/2006 tentang Pemisahan Kekayaan BUMN dari Kekayaan Negara, yang diprotes oleh kalangan penegak hukum karena dianggap menghambat usaha-usaha pemberantasan tindak pidana korupsi di Indonesia.

Ketidaktegasan posisi BUMN Persero sebagaimana yang disebutkan di atas telah menimbulkan keragu-raguan baru yakni apakah kekayaan negara yang telah dipsahkan ke dalam suatu perseroan masih tetap dianggap sebagai kekayaan negara. Dengan demikian, perlu ketegasan apakah asset BUMN Persero dapat dikatakan sebagai kekayaan negara, dan apakah kerugian BUMN Persero merupakan kerugian negara? Untuk menjawab hal tersebut perlu mencari hubungannya dengan maksud dan tujuan BUMN Persero didirikan.

Pasal 1 ayat (2) UU BUMN menyebutkan bahwa Perusahaan Perseroan, yang selanjutnya disebut Persero, merupakan BUMN yang berbentuk perseroan terbatas yang modalnya terbagi dalam saham yang

\footnotetext{
${ }^{15}$ Ibid. Lihat juga Arifin P. Soeriaatmadja, Hukum Keuangan Negara Pasca 60 Tahun Indonesia Merdeka, Masalah dan Prospeknya bagi Indonesia Inc < http://www.ppatk.go.id > diakses tangga1 15 September 2005.
} 
seluruh atau paling sedikit 51\% sahamnya dimiliki oleh negara Republik Indonesia yang tujuan utamanya mengejar keuntungan.

Berdasarkan pengertian tersebut maka ciri-ciri pokok BUMN Persero sebagai berikut : ${ }^{16}$

1) Status hukumnya merupakan badan hukum berbentuk PT.

2) Usahanya untuk memupuk keuntungan.

3) Hubungan usahanya diatur menurut hukum perdata.

4) Modal seluruhnya atau sebagian merupakan milik negara dari kekayaan negara yang dipisahkan, dengaxt demikian dimungkinkan adanya kerjasama dengatti pihak swasta dan adanya penjualan saham perusahaan milik negara.

5) Peranan pemerintah adalah sebagai pemegang saham dalam perseroan.

Ciri-ciri khas dari sebuah PT yakni merupakan badan hukum yang didirikan berdasarkan perjanjian sehingga mempunyai lebih dari 1 (satu) orang pemegang saham. PT melakukan kegiatan usahanya dengan modal dasar yang seluruhnya terbagi atas saham dan memenuhi persyaratan-persyaratan yang ditentukan dalam undang-undang. Dari pengertian PT tersebut di atas, ciri-ciri dasar dari sebuah PT yaitu: ${ }^{17}$

1) PT sebagai subjek hukum terpisah dari pendiri maupun pengelolanya (persona standi in judicio) termasuk kepemilikan kekayaan dan asetnya. Hal ini berarti bahwa sejak PT memperoleh status sebagai badan hukum, sejak saat itu pula hukum mernperlakukan pemegang saham dan direksi terpisah dari PT itu sendiri. Sebuah perseroan dengan tanggung jawab yang terbatas tidak

\footnotetext{
${ }^{16} \mathrm{Ibid}, \mathrm{hlm} .3$.

17 Ibid.
}

hanya kepemilikan kekayaan oleh perusahaan saja yang terpisah dengan uang yang dimiliki oleh orang yang menjalankan perseroan, melainkan juga pemegang saham tidak bertanggung jawab atas utang perseroan dimaksud. PT dapat memiliki harta dan segala hak dan kewajiban yang terpisah dari harta dan kewajiban yang dimiliki oleh para direksi dan pemegang saham.

2) Pemegang saham mempunyai porsi:

a) bertanggung jawab hanya pada apa yang disetorkan atau tanggung jawab terbatas (limited liability).

b) tidak bertanggung jawab atas kerugian perseroan melebihi dari nilai saham yang telah diambilnya.

c) tidak bertanggung jawab secara pribadi atas perikatan yang dibuat atas nama perseroan.

3) Adanya pemisahan fungsi antara pemegang saham dengan direksi.

4) Aset perseroan dalam bentuk saham yang membuatnya sangat mudah untuk dialihkan, dijual, dan digadaikan.

5) Adanya pengurus yang diangkat dan adanya pendelegasian kewenangan dengan prinsip fidusia (entrusted fiduciary duties).

6) Adanya pihak penyandang dana yang disebut sebagai investor atau pemilik hak atas keuntungan, sehingga kekuasaan tertinggi berada pada Rapat Umum Pemegang Saham (RUPS).

Di pihak lain, sesuai dengan Pasal 61 ayat (1) UU Nomor 40 Tahun 2007 tentang Perseroan Terbatas, pemegang saham berhak mengajukan gugatan terhadap perseroan ke pengadilan negeri apabila dirugikam karena tindakan perseroan yang dianggap tidak adil dan tanpa alasan yang 
wajar sebagai akibat dari keputusan RUPS, Direksi, dan/atau Dewan Komisaris.

Dari uraian di atas, dapat dilihat bahwa penegak hukum melihat kredit macet yang terjadi di bank BUMN diketegorikan sebagai mengakibatkan kerugian negara, karena modal bank BUMN berasal dari kekayaan negara yang dipisahkan.

Ditinjau dari sudut hukum perdata, makna kekayaan negara yang dipisahkan berarti bahwa negara seharusnya tidak dibenarkan mencampuri pengelolaan korporasi yang dilakukan pengurus bank BUMN tersebut. Apabila terjadi kelalaian yang dilakukan oleh direksi dan mengakibatkan kerugian bagi bank BUMN, pertanggungjawaban dapat dimintakan secara perdata bukan pidana, kecuali RUPS menentukan lain. Berbeda halnya apabila frase tersebut berbunyi "kekayaan negara yang disisihkan", dalam hal demikian negara masih aiperkenankan untuk melakukan campur tangan terhadap pengelolaan korporasi dari usaha bank BUMN, dan aturan tentang tindak pidana korupsi dapat diterapkan.

Di tinjau dari sudut pandang hukum perdata, ketika negara telah memisahkan kekayaannya untuk selanjutnya diserahkan agar dikelola oleh pengurus bank (dalam hal ini pengurus bank BUMN), pertanggungjawaban secara yuridis teralih kepada korporasi bukan lagi di tangan pengurus bank dimaksud. Dalam hukum korporasi, kepengurusan BUMN dilaksanakan oleh direksi yang bertanggung jawab penuh atas kegiatan pengurusan baik di dalam maupun di luar pengadilan semata-mata untuk kepentingan dan tujuan BUMN. Dalam melaksanakan tugasnya, direksi diawasi oleh Dewan Komisaris. Apabila direksi melakukan kesalahan baik karena melakukan perbuatan melawan hukum (onrechtmatige daad) maupun karena wan prestasi yang mengakibatkan kerugian bagi perusahaan maupun pihak ketiga, direksi akan mempertanggungjawabkan perbuatan hukumnya secara perdata melalui RUPS.

Dari sudut pandang hukum perdata, masalah internal dalam perusahaan tidak diperkenankan untuk dicampuri oleh pihak luar seperti penegak hukum, kecuali hasil keputusan RUPS menghendaki lain. Pemerintah harus dapat meletakkan dirinya sesuai dengan proporsinya, terutama dalam hal pemerintah bukan pemegang saham seratus persen. Pemerintah harus mengakui keberadaan pemegang saham minoritas lainnya, dan segala sesuatunya harus diputus melalui RUPS yang diagendakan untuk itu. Sebagaimana halnya pemegang saham yang mempunyai hak-hak dan kewajiban, pemegang saham minoritas yang merasa dirugikan oleh tindakan pemerintah sebagai pemegang saham mayoritas, pun dapat mempergunakan haknya untuk menuntut hal tersebut secara perdata ke pengadilan negeri.

Uraian mengenai modal bank BUMN yang berasal dari kekayaan negara yang dipisahkan membawa kita kepada pertanyaan selanjutnya, yakni apakah dengan demikian penyelesaian secara pidana kredit macet yang terdapat pada bank-bank BUMN menjadi sebuah jalan terbaik untuk mengembalikan kredit macet tersebut kembali ke dalanl portofolio bank? Pertanyaan ini sangat relevan karena, apabila pemerintah mendapatkan pengembalian dari kredit macet yang ditempuh melalui upaya-upaya pidana, uang pengembalian ex kredit macet tersebut akan disetorkah kembali ke bank semula dan bukan ke APBN, karena sewaktu kredit dinyatakan macet dan ditangani aparat penegak hukum, pada dasarnya tidak terjadi pengurangari penyertaan modal pemerintah (PMP) pada bank BUMN tersebut.

Menjadi pertanyaan berikutnya yaitu apakah terdapat sengketa perdata dalam kasus korupsi dan kondisi yang hagaimana 
yang memungkinkan perpindahan jalur dari sisi pidana ke sisi perdata dalam tindak pidana korupsi? Untuk memperoleh jawaban atas kemungkinan tersebut, Amir Syamsuddin menyebutkan perlunya diperhatikan hal-hal sebagai berikut : ${ }^{18}$

1) Dalam kasus korupsi terdapat beberapa unsur penting antara lain (a) unsur melawan hukum, (b) unsur memperkaya diri sendiri atau orang lain, dan (c) unsur merugikan keuangan negara. Unsur memperkaya diri sendiri atau merugikan keuangan negara memang erat kaitannya dengan masalah keperdataan, tetapi unsur melawan hukum lebih bersifat publik yang menunjukkan perbuatan pidana yang bertentangan dengan kepentingan publik yang diancam dan dapat dijatuhi hukuman pidana. Oleh karena itu, jelas bahwa walaupun ada sifat perdatanya, tetapi sebuah kasus korupsi tidak dapat dialihkan menladi kasus perdata karena perbuatan korupsi tidak hanya menyangkut kekayaan negara atau uang negara yang sifatnya perdata, tetapi juga menyangkut perbuatan pidana. Berkaitan dengan perbuatan pidana, korupsi harus dihukum sesuai dengan ketentuan pidana karena melanggar peraturan perundang-undangan pidana yang berlaku (vide Pasal 4 UU Nomor 31 Tahun 1999 jo. UU Nomor 20 Tahun 2001 yang menyebutkan bahwa pengembalian kerugian negara tidak menghapus pidananya). Banyak sekali kasus korupsi yang terpenuhi unsur perbuatan melawan hukumnya, tetapi unsur kerugian negaranya tidak terpenuhi, sehingga

\footnotetext{
${ }^{18}$ Amir Syamsuddin, Pendekatan Hukum Perdata dalam Kasus Korupsi di Indonesia, PPH Newsletter No. 66, September 2006, hlm. 7-8.
}

sebuah kasus korupsi tidak semuanya dapat dialihkan ke kasus perdata.

2) Apabila dalam kasus korupsi terbukti dan terpenuhi semua unsur dari ketentuan pidana menurut perundang-undangan korupsi, pelaku korupsi harus dihukum dan dijatuhkan pidana dan semua kekayaan pelaku korupsi yang terkait dengan perbuatan korupsinya harus dirampas untuk negara. Dan apabila tidak semua unsur dari ketentuan pidana korupsi terpenuhi, perlu dilihat apabila unsur merugikan keuangan negara atau unsur memperkaya diri sendiri dan orang lain terpenuhi atau tidak. Apabila terpenuhi, permasalahan mengenai kekayaan yang diperoleh dan keuangan negara yang hilang dapat diajukan tuntutan perdata [vide Pasal 32 ayat (1) UU Nomor 20 Tahun 2001]. Jikalau unsur kerugian negara tidak terpenuhi berarti tidak dapat dilakukan tuntutan perdata.

Dari uraian di atas kelihatan bahwa kasus korupsi dapat dimasukkan kedalam wilayah perdata dan sekaligus juga ke wilayah pidana, namun Amir Syamsuddin lebih banyak menitikberatkan segi unsur pidana dibandingkan dengan unsur perdatanya, kemungkinan karena pengaruh UU Pemberantasan Tindak Pidana Korupsi dan yang bersangkutan banyak menggeluti hal itu. Selanjutnya, Amir Syamsuddin menyebutkan bahwa upaya pengembalian uang negara merupakan tujuan utama politik hukum penanganan tindak pidana korupsi di Indonesia. ${ }^{19}$ Walaupun akhirakhir ini telah terdapat pergeseran ke arah penghukuman untuk menimbulkari efek jera (deterrent effect) di masyarakat, tetapi upaya pengembalian uang negara yang hilang akibat perbuatan korupsi juga

\footnotetext{
${ }^{19}$ Ibid, hlm. 7.
} 
menjadi tujuan utama. Kasus Bantuan Likuiditas Bank Indonesia (BLBI) merupakan contoh dari upaya pengembalian uang negara melalui pendekatan perdata, sedangkan kasus-kasus lain seperti kasus Komisi Pemilihan Umum (KPU) dan sebagainya lebih banyak mengarah kepada penghukuman. ${ }^{20}$

\section{PENUTUP}

\section{A. KESIMPULAN}

1. Tugas dan tanggung jawab dari sebuah bank mencakup kegiatan menghimpun dana dari masyarakat, menyalurkan kembali dana yang dihimpun tersebut kepada masyarakat/dunia usaha yang membutuhkan, serta menyediakan layanan jasa-jasa tertentu di bidang keuangan dan perbankan. Reputasi perbankan nasional dipengaruhi oleh kualitas dan integritas para bankirnya, yang harus mampu ditunjukkan oleh para bankir nasional untuk menjawab tudingan sementara kalangan mengenai korelasinya dengan banyaknya kredit macet yang terdapat pada bank-bank umum dewasa ini, khususnya di bank BUMN.

2. Bahwa perangkat hukum pidana dan perdata telah memberikan pedoman dalam penyelesaian kasus kredit macet. Persoalannya sekarang adalah apakah peranti hukum yang tersedia tersebut telah didayagunakan secara optimal dan konsisten oleh pemerintah dalam menyelesaikan kasus kredit macet di Indonesia. Kredit macet yang terjadi di bank BUMN diketegorikan sebagai mengakibatkan kerugian negara, karena modal bank BUMN berasal dari kekayaan negara yang dipisahkan. Ditinjau dari sudut hukum perdata, makna kekayaan negara yang dipisahkan berarti bahwa negara seharusnya tidak dibenarkan men- campuri pengelolaan korporasi yang dilakukan pengurus bank BUMN tersebut. Apabila terjadi kelalaian yang dilakukan oleh direksi dan mengakibatkan kerugian bagi bank BUMN, pertanggungjawaban dapat dimintakan secara perdata melalui gugatan ke pengadilan bukan pidana, kecuali RUPS menentukan lain.

\section{B. SARAN}

Dalam konteks pembahasan tanggung jawab yuridis bankir berkaitan dengan kredit macet, di dalamnya termasuk pegawai bank yang merupakan pihak pelaksana tugas. Seluruh komponen pejabat bank (bankir), baik yang memegang tampuk pimpinan tertinggi maupun yang berada pada level menengah memiliki tanggung jawab yuridis terhadap semua aktivitas operasional bank, sesuai dengan tugas dan fungsinya masing-masing dalam organisasi. Dengan kata lain, tugas fiduciary duty dan duty of skill and care bukan hanya berlaku bagi bankir saja, tetapi juga berlaku terhadap pelaksana dalam melaksanakan tugas-tugasnya sesuai dengan uraian tugas dan tanggung jawabnya.

\section{DAFTAR PUSTAKA}

Badrulzaman, Mariam Darus., Perjajian Kredit Bank, Alumni, Bandung. 1983.

------., 1994. Aneka Hukum Bisnis, P.T. Alumni, Bandung.

--------., 2001. KUHPerdata, Buku ke III, Hukum Perikatan dengan Penjelasan, P.T. Alumni, Bandung.

Black, Henry Campbell., Black's Law Dictionary, 5th edition, West Publishing Co., St. Paul, Minn, 1979, hlm 140.

Chatamarrasjid, 2000. Menyingkap Tabir Perseroan (Piercing the Corporate Veil), Citra Aditya Bakti, Bandung.

Djumhana, M., 2000. Hukum Perbankan di Indonesia, cetakan III, Citra Aditya Bakti, Bandung. 
---------., Perjanjian Kredit Bank, CV Gramedia. Jakarta, 2000.

------------., Asas-Asas Hukum Perbankan Indonesia, Citra Aditya Bakti, Bandung, 2008.

Fuady, Munir., 1996, Hukum Perkreditan Kontemporer, PT. Citra Aditya Bakti, Bandung.

2002. Doktrin-Doktrin Modern dalam Corporate Law dan Eksistensinya dalam Hukum Indonesia, Citra Aditya Bakti, Bandung.

---------., 2003, Perseroan Terbatas Paradigma Baru, PT. Citra Aditya Bakti, Bandung,

--------., 2003. Hukum Perbankan Modern, Buku Kesatu, Citra Aditya Bakti, Bandung.

Hasan, Dj., Lembaga Jaminan Kebendaan Bagi Tanah dan Benda Lain Yang Melekat Pada Tanah Dalam Konsepsi Penerapan Asas Pemisahan Horisontal, Citra Aditya Bakti, Bandung, 1996.

Khairandy, Ridwan., Perseroan Terbatas Doktrin, Peraturan PerundangUndangan dan Yurisprudensi, Edisi Revisi, Total Media, Yogyakarta, 2009.

Rahardjo, S., 1980. Ilmu Hukum, P.T. Alumni, Bandung.

Satrio, J., 2002. Hukum Jaminan, Hak Jaminan Kebendaan, cetakan IV, Citra Aditya Bakti, Bandung.

Sjahdeini, S.R., 1993. Kebebasan Berkontrak dan Perlindungan yang Seimbang bagi Para Pihak dalam Perjanjian Kredit Bank di Indonesia, Institut Bankir Indonesia, Jakarta.

------------., Pertanggungjawaban Pidana Korporasi, cetakan ke-2, Grafiti Pers, Jakarta, 2007.

Subekti, R., Aneka Perjanjian. Alumni, Bandung, 1982.

Supramono, Gatot., Perbankan dan Masalah Kredit Suatu Tinjauan Bidang Yuridis, Rineka Cipta, Jakarta, 2009. http://ridwanaz.com/umum/pengertianbank/

http://www.sarjanaku.com/2012/06/penge

rtian-bank-dan-jenisnya.html.

http://ferina061192.blogspot.com/2012/04

/kasus-aspek-hukum-dalamekonomi-tugas.html

http://pn-

yogyakota.go.id/pnyk/pengertianperadilan.html

Soeriaatmadja, A. P., 2005. Hukum Keuangan Negara Pasca 60 Tahun Indonesia Merdeka, Masalah dan Prospeknya bagi Indonesia Inc, < http: / /www.ppatk.go.id diakses tangga115 September $2005>$

Sumber-Sumber Lain : 